\title{
Role of calcium antagonists in cardiovascular therapy
}

\author{
HENRY DARGIE, * EDWARD ROWLAND, DENNIS KRIKLER \\ From the Division of Cardiovascular Disease, Royal Postgraduate Medical School, Hammersmith Hospital, London
}

SUMMARY The development of drugs which selectively block the "slow" channels by which calcium enters the cell (calcium antagonists) has provided valuable information about the role of transmembrane calcium exchange in man and has offered new therapeutic approaches. The principal effect on the cardiovascular system is relaxation of vascular smooth muscle but some of these drugs also have electrophysiological effects, especially slowing of conduction in the atrioventricular node; verapamil is the agent of choice in supraventricular tachycardia. Significant myocardial depression does not usually occur with doses used clinically. The calcium antagonists have specific value in variant angina. By causing peripheral vasodilatation they are also effective hypotensive agents and do not cause reflex tachycardia in chronic use. Their value in hypertrophic cardiomyopathy and in the protection of ischaemic myocardium remains to be proven.

The term "calcium antagonist" was introduced by Fleckenstein in 1969 to describe the actions of compounds which had both coronary vasodilator and negative inotropic properties ${ }^{2}$; the effects of these compounds on the myocardium were identical to those of calcium deficiency, which had been recognised by Ringer in $1882 .{ }^{3}$ In recent years the pivotal role of calcium in connecting the dual processes of excitation of the cell membrane and contraction of the muscle fibres has been well documented. ${ }^{4}$ Though transmembrane exchange of sodium and potassium is the basis of cell membrane electrical activity, it has become clear that calcium ions are also important in the generation of normal and abnormal pacemaker activity and in the conduction of these impulses through the specialised tissues of the heart. ${ }^{5}$

We propose to describe and explain the effects of several calcium antagonists on the cardiovascular system based on current knowledge of transmembrane calcium exchange.

\section{Excitation-contraction coupling}

\section{(a) EXCitation}

Excitation of mammalian myocardium depends on the operation of channels in the cell membrane through which ions may move inward from the extracellular space. ${ }^{6}$ Three such inward channels are recognised on the basis of ionic selectivity, specificity of inhibition by chemical agents, and time constant of activation. ${ }^{78}$ The

* Supported by the British Heart Foundation; present address: Department of Cardiology, Western Infirmary, Glasgow.

Received for publication 13 January 1981 sodium or fast inward channel, which is blocked by tetrodotoxin, has a very short activation time, during which influx of sodium is rapid. The slow inward channel can be blocked by manganese and nickel and has a longer period of activation, during which there is less rapid influx of calcium (and some sodium). A third inward channel, carrying magnesium, which has an intermediate activation time, and which can be blocked by catecholamines, has recently been described. ${ }^{9}$

The action potentials found in different anatomical (and functional) areas of the heart can be explained in terms of different components of slow and fast channel activity. In cardiac muscle fibres the initial rapid upstroke of the action potential (phase 0 ) results from a rapid influx of sodium through the fast channels upon depolarisation of the cell membrane. Rapid repolarisation (phase 1) occurs when the sodium channels close and is then delayed by the continuing slow influx of calcium which causes the plateau of the action potential (phase 2). Repolarisation continues with the closure of these channels (phase 3).

In the sinus node and in the central part of the atrioventricular node ${ }^{10}$ activation is largely calciumdependent and phase 0 there is slower than in the muscle fibres. Furthermore, after repolarisation the pacemaking and conducting tissues undergo spontaneous diastolic depolarisation associated with calcium influx (phase 4).

\section{(b) CONTRACTION}

When the intracellular concentration of calcium reaches $10^{-6}$ molar the contractile proteins actin and myosin interact. " This is highly dependent on the slow 
channel influx which triggers release of calcium from intracellular storage sites, including the sarcoplasmic reticulum $^{12}$; the rapid rise in free intracellular calcium initiates the hydrolysis of adenosine triphosphate to adenosine diphosphate by myofibrillar adenosine triphosphatase, releasing energy which is used to slide the actin filaments along the myosin filaments, thus generating tension. ${ }^{2}$

\section{Calcium antagonism}

The prototype of the new family of drugs, which Fleckenstein called calcium antagonists, was verapamil. ${ }^{13}$ Since then a number of compounds have been found to have similar properties; among the most important of these are the methoxy derivative of verapamil, D600; the 1,4 dihydropyridine, nifedipine, and its congener niludipine; the diphenylamines, prenylamine and fendiline; perhexiline; and diltiazem. ${ }^{14-18}$ Unlike other groups of drugs with a common action, for example the beta-adrenoceptor antagonists, the calcium antagonists share no common molecular configuration. Differences have been observed in the way these compounds act; verapamil delays recovery of the slow channel, while nifedipine impairs its activation ${ }^{19}$; in addition, the binding of verapamil to muscarinic receptors may be relevant to its specific antiarrhythmic properties. ${ }^{20}$ This has led to difficulty with the classification of calcium antagonists. ${ }^{21}$ At the present time Fleckenstein restricts this term to those drugs whose outstanding property is completely and reversibly to inhibit the effects of calcium on excitation-contraction coupling in the heart or smooth muscle, or both ${ }^{22}$ : he prefers this to an alternative, slow-inward-channel inhibition, but the semantic debate continues.

The main actions of the calcium antagonists in man may be inferred from the calcium-dependent processes described in vitro; thus verapamil inhibits myocardial excitation-contraction coupling with resultant myocardial depression, relaxes vascular smooth muscle, and depresses pacemaker activity: all these effects are reversed by calcium or isoprenaline. ${ }^{1213}$

\section{(a) MYOCARDIAL EFFECTS}

Calcium influx leads to activation of myofibrillar adenosine triphosphatase which converts phosphatebound energy into mechanical work: thus calcium influx is an important determinant of myocardial oxygen consumption. Calcium antagonists, therefore, by limiting calcium influx, reduce calcium-dependent splitting of adenosine triphosphate, which in turn reduces myocardial oxygen demand; together with these events the force of myocardial contraction is reduced. ${ }^{21323}$ While this action could potentially be hazardous, it must be viewed in the context of myocardial function in vivo. Firstly, a fall in arterial pressure produces a reflex increase in sympathetic activity $^{2}$; secondly, by relaxing vascular smooth muscle calcium antagonists decrease left ventricular afterload. ${ }^{24}$ As the effect on peripheral vascular smooth muscle is seen at 10 to $30 \%$ of the dose required to produce excitation-contraction uncoupling, ${ }^{23}$ the vascular effects outweigh and offset the central cardiac effects in man, and in practice verapamil or nifedipine usually increase the cardiac output slightly. ${ }^{2425}$

\section{(b) VASCULAR EFFECTS}

Relaxation of vascular smooth muscle has been most extensively studied in spiral strips of the large calibre extramural coronary arteries. ${ }^{526}$ These strips lose their contractile tone in a calcium-free medium but recover it completely on restoration of calcium to the medium. Calcium antagonists counter the effects of vasoconstrictors like histamine, serotonin, ergotamine, acetylcholine, and cardiac glycosides ${ }^{27}$ by blocking excitation-contraction coupling. Systematic vascular resistance declines, ${ }^{24}$ indicating an effect on the peripheral vasculature.

\section{(c) PACEMAKER ACTIVITY AND IMPULSE}

TRANSMISSION

The reduction of cardiac contractility in a calcium-free medium is paralleled by a decrease in heart rate, and verapamil, diltiazem, and nifedipine also suppress sinuatrial and atrioventricular pacemaker activity in vitro, ${ }^{28-30}$ effects that are reversed by isoprenaline and by extra calcium. ${ }^{2}$ But in man not all calcium antagonists affect sinus node or atrioventricular nodal function as they do in other species in vitro; at doses used clinically nifedipine appears to lack electrophysiological effects in man. ${ }^{31}$ Verapamil has been shown to exert a chronotropic effect on sinus node activity by a baroreceptor mediated increase in sympathetic activity, ${ }^{32}$ and the similarity in the degree of acceleration of sinus node discharge after both drugs suggests that their peripheral effects are similar. ${ }^{31}$

The therapeutic potential for calcium antagonists is thus considerable. Definite indications include angina, hypertension, and arrhythmias; there may well be a place in hypertrophic cardiomyopathy; a more speculative possibility is the protection of ischaemic myocardium.

\section{Angina}

\section{THEORETICAL CONSIDERATIONS}

Angina pectoris is usually associated with obstructive coronary artery disease which restricts the extent to which myocardial blood flow can be augmented when the demand for oxygen is increased as, for example, during exercise. While drugs which reduce myocardial 
work, such as nitrates and beta-blockers, are effective in angina, so too potentially are calcium antagonists; they could act in this way not only by decreasing myocardial work but also by increasing perfusion through coronary vasodilatation. In several animal species calcium antagonists increase myocardial blood flow ${ }^{33-35}$ and they can reduce coronary vascular resistance and increase coronary blood flow in patients with normal coronary arteries; but when there is coronary artery disease, even though coronary arteriolar resistance may be decreased at rest, evidence for an increase in coronary blood flow, though conflicting, does exist. ${ }^{36-38}$ Calcium antagonists undoubtedly reverse or inhibit coronary vasospasm: this can be observed directly during coronary arteriography or inferred from haemodynamic or non-invasive monitoring of patients with variant (Prinzmetal's) angina. ${ }^{39} 40$

\section{CLINICAL STUDIES IN ANGINA}

(a) Variant angina

Angina at rest associated with ST segment elevation (or depression) is believed to be caused by a temporary increase in coronary arterial tone leading to occlusion of the vessel. ${ }^{41}{ }^{42}$ While controlled trials in this syndrome are lacking, complete remission of ischaemic events seen in most patients with documented spasm ${ }^{39}$ 40 43-45 suggests a major role for calcium antagonists; indeed their withdrawal may lead to prompt recurrence of symptoms. ${ }^{3944}$ In 12 patients with unstable angina and frequent episodes of ST segment deviation at rest, verapamil ( $480 \mathrm{mg} /$ day) was compared with placebo in a double-blind study conducted in the coronary care unit ${ }^{46}$; nine of these patients showed direct evidence of coronary spasm either at angiography or with myocardial scintigraphy. During the two treatment periods transient ischaemic attacks were reduced from 123 and 130 episodes during placebo to 31 and 23 episodes, respectively. A similar response was seen with nifedipine in eight patients with variant angina with normal or mildly abnormal coronary arteriograms ${ }^{44}$; this was further confirmed in a study of 127 patients with coronary spasm in which it decreased anginal frequency from an average of 16 attacks a week to two: in $63 \%$ control was complete. ${ }^{47}$

\section{(b) Chronic stable angina}

There are few properly controlled clinical trials on the efficacy of calcium antagonists in chronic stable angina, compared with other standard treatment.

In a single-blind controlled trial on 10 patients nifedipine $(60 \mathrm{mg} /$ day $)$ reduced anginal frequency from 11 episodes a patient a week to six and glyceryl trinitrate consumption from nine tablets a week to four; this was associated with a moderate increase in exercise duration. ${ }^{48}$ In our own double-blind studies ${ }^{49}$ in 16 patients, nifedipine $(60 \mathrm{mg} /$ day $)$ reduced anginal frequency and glyceryl trinitrate consumption from 22 to 12 episodes a week and from 18 to 11 tablets a week. We also showed that nifedipine reduced the area of exercise-induced myocardial ischaemia by $35 \%$, as assessed by 16 point praecordial mapping, and the total number of episodes of ST depression on ambulatory monitoring fell by $51 \%$. Sixty per cent of these episodes were asymptomatic and these responded in exactly the same way to nifedipine as the episodes associated with chest pain.

Early studies of verapamil at lower doses gave equivocal results ${ }^{50}$ but during double-blind clinical trials, doses of $360 \mathrm{mg} /$ day $^{51}{ }^{52}$ reduced anginal frequency and glyceryl trinitrate consumption by approximately $50 \%$, and significantly increased exercise duration.

Few comparative data are available for verapamil and nifedipine but in a single-blind placebo-controlled acute study $10 \mathrm{mg}$ nifedipine and $160 \mathrm{mg}$ verapamil given orally increased exercise duration similarly when compared with placebo ${ }^{53}$ : if the same criteria are examined nifedipine and verapamil in appropriate doses are probably equipotent in chronic stable angina.

Several studies of the combination of nifedipine and beta-blockers uniformly show it to have a distinct beneficial effect approximately equivalent to the additive effects of each drug. ${ }^{495455}$ Our studies showed that the area of exercised-induced ischaemia and the frequency of ischaemic events detected by ambulatory monitoring were reduced by 90 and $95 \%$, respectively ${ }^{49}$ : in another study the total work performed increased by $41 \%$ with the combination of $30 \mathrm{mg}$ nifedipine per day and metoprolol or alprenolol. ${ }^{54}$ Neither cardiac failure $^{4955}$ nor change in atrioventricular conduction time occurred on the combination. ${ }^{54}$ Studies with oral verapamil and beta-blockers are now in progress.

\section{MECHANISM OF ANTIANGINAL EFFECT}

The mechanisms of antianginal action are complex. The rate-pressure product in exercise duration studies is similar to that on placebo and even for a given workload no significant difference occurs, unlike the situation with beta-blockers. ${ }^{36} 3749$ Intracoronary injection of small $(0.1 \mathrm{mg})$ doses of nifedipine had the same effect on exercise duration as $1 \mathrm{mg}$ given intravenously despite the absence of peripheral effects with the former and the return of an initially slightly increased coronary flow with both doses to pre-treatment values. ${ }^{35}$ But increased flow to areas of ischaemia induced by pacing has been described ${ }^{37}$ and the rate pressure product may not detect small reductions in myocardial oxygen consumption during exercise. Thus in variant angina, calcium antagonists are almost specific, while in pure exercise-induced angina they are moderately effective, and less so than beta-blockers. ${ }^{48}$ The pronounced benefit, however, of combining a beta- 
blocker with a calcium antagonist has conspicuously improved the therapy of chronic stable angina, but the precise mode of action and role of calcium antagonists remain to be clarified.

\section{Protection against acute ischaemic damage}

Ischaemia leads to a high cytosolic calcium concentration partly by impairing the mechanism by which calcium is pumped out of the cell. ${ }^{5657}$ This leads to increased use of adenosine triphosphate and impairment of mitochondrial function with decreased production of adenosine triphosphate. ${ }^{56}$ Limitation of calcium influx is therefore a logical approach to myocardial protection against ischaemia. Beta-blockers probably owe part of their protective effect to antagonism to catecholamine-stimulated calcium influx ${ }^{58}$ and calcium antagonists offer an alternative approach.

In experimental animals numerous methods of assessment of ischaemic damage have indicated a protective effect of several calcium antagonists. ${ }^{59-62}$ Decreased functional impairment in terms of resting tension, contractility, and systolic function have also been shown with verapamil, nifedipine, and diltiazem. ${ }^{63-65}$ In rabbit hearts the increased cellular fragility produced by ischaemia can be prevented by pretreatment with nifedipine. ${ }^{66}$ Caution is however necessary before extrapolating this to the use of calcium-free cardioplegic solutions in cardiopulmonary bypass, as verapamil does not protect heart muscle against the deleterious effects of restoring the calcium concentration after a period of calcium-free perfusion (the calcium paradox). ${ }^{67}$

Protective effects may be dose related. Myocardial perfusion, epicardial electrocardiographic wave forms, and creatine kinase activity yielded beneficial results with lower doses of nifedipine: but in high doses a distinct fall in blood pressure occurred, resulting in decreased coronary perfusion. ${ }^{68}$ Evidence of protection against ischaemia in man is as yet lacking and in clinical use care must be taken to avoid sudden large falls in blood pressure which might lead to a situation similar to that reported in experimental studies. Anecdotal reports of cardiac pain precipitated by nifedipine are difficult to evaluate. ${ }^{69}$

\section{Arrhythmias}

\section{(a) SU PRAVENTRICULAR}

Of all the calcium antagonists verapamil is the most effective antiarrhythmic agent, and it is almost universally successful when given intravenously $(0.15 \mathrm{mg} / \mathrm{kg}$ body weight) in reciprocating atrioventricular tachycardia, whether intranodal or in association with an accessory atrioventricular connection, for example as in the Wolff-Parkinson-White syndrome. ${ }^{70}{ }^{71}$ Its potent action may be diminished by postural or reflex increases in autonomic tone, which may explain the slightly lower incidence of immediate response when the tachycardia is induced during intracardiac electrophysiological study. ${ }^{72}$ In a formal comparison, success was achieved in 19 out of 20 patients with verapamil as compared with eight out of 20 with practolol. ${ }^{73}$ While verapamil lengthens atrioventricular nodal conduction time, nifedipine, given in equivalent dose, lacks this property and does not terminate tachycardia. ${ }^{31}$

In atrial fibrillation, the usual response to intravenous verapamil is slowing and a greater degree of regularity in the ventricular response, reversion to sinus rhythm being rare; it is seen in occasional cases of atrial flutter, but here again the major influence is an increase in the degree of atrioventricular block. ${ }^{74}$ In both atrial fibrillation and flutter, this transient intravenous response can be clinically helpful: some studies have shown that oral verapamil can be used to control the ventricular response satisfactorily in atrial fibrillation. ${ }^{75}$ A proportion of patients whose atrioventricular tachycardia is terminated by intravenous verapamil have further attacks successfully prevented by oral administration, but we lack a firm basis for the prediction of such a response: the best results were seen (10 of 12 cases) with intranodal tachycardia, response being less good with verapamil alone in pre-excitation, though combined therapy may work. ${ }^{76}$ Especially with intravenous use, there is a risk of sinuatrial depression in patients with sinuatrial disease or on betablockers ${ }^{707377}$; these situations contraindicate the administration of verapamil. Oral verapamil and digitalis can, however, safely be combined. ${ }^{78}$ While hypotension may occur, this is usually mild and transient; indeed verapamil can be given without ill-effect in patients with myocardial infarction. ${ }^{79}$

\section{(b) VENTRICULAR ARRHYTHMIAS}

Though electrophysiological studies ${ }^{80}$ suggest that some ventricular arrhythmias arise because ischaemic cells become depolarised by the slow as opposed to the fast inward channel, and that this is blocked by verapamil, this drug has not proved effective under experimental conditions. ${ }^{81}$ Indeed, verapamil given during electrophysiological testing failed to inhibit chronic recurrent ventricular tachycardia. ${ }^{82}$ Some ventricular extrasystoles, whether or not associated with acute myocardial infarction, are suppressed by intravenous verapamil, ${ }^{783}$ but clinical value against more serious ventricular arrhythmias has not been demonstrated.$^{84}$ There is one clear exception: where coronary spasm induces ventricular arrhythmias, reversal of the spasm by a calcium antagonist has 
secondary but significant antiarrhythmic value. ${ }^{85}$ Though there is good evidence that verapamil protects against the ventricular fibrillation in dogs caused either by coronary artery occlusion ${ }^{8687}$ or by release of occlusion, its clinical value under these circumstances would be difficult to demonstrate, and such evidence is lacking.

\section{Hypertension}

Acute haemodynamic studies have shown the characteristic effects of peripheral vasodilatation in that arterial pressure falls because of reduction in peripheral resistance and is accompanied by a baroreflex mediated increase in heart rate ${ }^{88} 89$ Since the principal haemodynamic abnormality in essential hypertension is an increase in peripheral vascular resistance, use of drugs which lower peripheral vascular resistance by a direct action on arteriolar smooth muscle is rational. The observation of increased calcium transport in arteriolar smooth muscle of rats with experimental hypertension ${ }^{90}$ provides a further stimulus to investigate its possible role in essential hypertension.

A fall of approximately $28 \%$ in both systolic and diastolic pressure occurred in hypertensive patients after $30 \mathrm{mg}$ nifedipine sublingually; this was accompanied by an increase in heart rate of $17 \%$ and an increase in plasma renin activity. Both effects were blocked by propranolol, which also caused a further slight reduction in blood pressure. ${ }^{91}$ In our own double-blind studies, nifedipine $(60 \mathrm{mg} /$ day for one month) reduced supine and standing systolic and diastolic blood pressure by 15 and $20 \%$ and by 21 and $23 \%$, respectively. ${ }^{92}$ In another placebo-controlled double-blind study, nifedipine in a dose of only 30 $\mathrm{mg} /$ day produced no further fall in blood pressure in patients incompletely controlled on other drugs. ${ }^{93}$ No increase in heart rate was found in chronic studies during treatment. ${ }^{92}$

In adouble-blind placebo-controlled crossover study, verapamil produced dose-dependent reductions in diastolic blood pressure of $18 \mathrm{mmHg}$ with $240 \mathrm{mg} /$ day and $22 \mathrm{mmHg}$ with $360 \mathrm{mg} /$ day. ${ }^{94}$ In a further study, when verapamil was substituted for existing drugs better control was obtained, and the reductions of blood pressure from baseline values were similar to those obtained in the original placebo-controlled study. ${ }^{95}$ Despite these impressive reductions in blood pressure there was no significant increase in heart rate like that shown in acute studies. This difference in the acute and chronic effects of calcium antagonists is now well documented: it may reflect either an intrinsic effect of the drug, evident only on chronic administration, or a true physiological adjustment such as resetting of the baroreflex.

With oral treatment it is also important to know whether calcium antagonists may be safely combined with other drugs, especially beta-blockers. Both classes of drugs can depress myocardial contractility, and betablockers share, at least with verapamil, a depressant effect on atrioventricular conduction. Nifedipine and propranolol have, however, been usefully and safely combined, ${ }^{9192}$ but the long-term effects of other calcium antagonist/beta-blocker combinations remain to be documented.

\section{Hypertrophic cardiomyopathy}

Whether or not this disorder reflects an abnormally avid transmembrane calcium flux, as is thought to explain the hereditary cardiomyopathy of Syrian hamsters, ${ }^{96}$ the potential benefits of verapamil are currently being appraised. Patients with hypertrophic cardiomyopathy whose left ventricular hypertrophy had remained unchanged or indeed become more severe while receiving propranolol showed substantial regression of hypertrophy on oral verapamil. ${ }^{97}$ This work has been further extended in a study of 22 patients who received a mean oral dose of verapamil of $480 \mathrm{mg} /$ day over an average of 15 months of treatment. Echocardiographic assessment was carried out in some cases and 10 patients underwent repeat cardiac catheterisation: in seven of these the left ventricular muscle mass was decreased and in the remaining three it was slightly increased; in a total of 39 patients observed over a mean follow-up period of 26.4 months the favourable results previously noted have been confirmed..$^{98}$ Indeed, in another study of 28 patients a conspicuous reduction in septal (but not posterior) wall thickness was found in all patients with asymmetric septal hypertrophy99; all also showed clinical and electrocardiographic improvement. Given intravenously to patients with left ventricular outflow obstruction, the gradient may be moderately reduced without detrimental effects on the cardiac output, pulmonary artery wedge or left ventricular enddiastolic pressures. ${ }^{100}$ In a double-blind placebocontrolled trial verapamil (up to $480 \mathrm{mg} /$ day) and propanolol (up to $320 \mathrm{mg} /$ day) increased exercise duration by $15 \%$ in 12 and 11 patients, respectively, out of 19. ${ }^{101}$ There was no correlation between the haemodynamic improvement noted acutely and exercise capacity or symptoms during the chronic study; neither drug relieved symptoms conspicuously more than placebo.

A potential benefit is the control of supraventricular arrhythmias that may complicate the disorder, ${ }^{102}$ but preliminary trials showed no benefit in these or ventricular arrhythmias when the drug was given orally to 30 patients. ${ }^{103}$ Thus any true benefit that may accrue will be long term and dependent on reduction in ventricular mass: the reports await corroboration. 


\section{Conclusions}

Calcium antagonists (a useful term to describe a diverse group of compounds with similar actions in isolated tissues) share the ability to counteract cardiac ischaemia and hypertension, but have varying actions on cardiac arrhythmias. The spectrum of therapeutic actions resembles that of the beta-blockers, to which calcium antagonists should be regarded as complementary. Thus in variant angina and supraventricular arrhythmias calcium antagonists are the drugs of choice, while in exertional angina beta-blockers are better, though here their efficacy can be enhanced by a calcium antagonist. The relative roles of these two groups of drugs in hypertension, hypertrophic cardiomyopathy, and protection of the ischaemic myocardium are currently being evaluated. As more is learned about their therapeutic efficacy, and their value recognised, calcium antagonists are beginning to assume their proper place, just as beta-blockers did more than a decade ago.

\section{References}

1 Fleckenstein A, Tritthart H, Fleckenstein B, Herbst A, Grün G. Eine neue Gruppe kompetitiver $\mathrm{Ca}^{++}$-Antagonisten (Iproveratril, D6000, Prenylamin) mit starken Hemeffekten auf die elektromekanische Koppelung im Warmblüter-myokard. Pfluegers Arch 1969; 307: R25.

2 Fleckenstein A. Specific inhibitors and promoters of calcium action in the excitation-contraction coupling of heart muscle and their role in the prevention or production of myocardial lesions. In: Harris P, Opie LH, eds. Calcium and the heart. London, New York: Academic Press, 1971: 135-8.

3 Ringer S. A further contribution regarding the influence of the different constituents of the blood on the contraction of the heart. 7 Physiol (Lond) 1882; 4: 29-42.

4 Ebashi, Endo M. Calcium ion and muscle contraction. Prog Biophys Mol Biol 1968; 18: 123-83.

5 Fleckenstein A. Specific pharmacology of calcium in myocardium cardiac pacemakers and vascular smooth muscle. Annu Rev Pharmacol Toxicol 1977; 17: 149-66.

6 Trautwein W. Membrane currents in cardiac muscle fibers. Physiol Rev 1973; 53: 793-835.

7 Beeler GW, Jr, Reuter H. Membrane calcium current in ventricular myocardial fibres. F Physiol (Lond) 1970; 207: 191-209.

8 Kohlhardt M, Bauer B, Krause H, Fleckenstein A. Differentiation of the transmembrane $\mathrm{Na} \& \mathrm{Ca}$ channels in mammalian cardiac fibres by the use of specific inhibitors. Pfluegers Arch 1972; 335: 309-22.

9 Späh F, Fleckenstein A. Evidence of a new, preferentially $\mathrm{Mg}$ carrying, transport system besides the fast $\mathrm{Na}$ and the slow $\mathrm{Ca}$ channels in the excited myocardial sarcolemma membrane. $7 \mathrm{Mol}$ Cell Cardiol 1979; 11: 1109-27.

10 Zipes DP, Fischer JC. Effects of agents which inhibit the slow channel on sinus node automaticity and atrio- ventricular conduction in the dog. $\operatorname{Circ} \operatorname{Res} 1974 ; 34$ : 184-92.

11 Adelstein RS. Myosin phosphorylation cell motility and smooth muscle contraction. Trends Biochem Sci 1978; 3: 27-30.

12 Fabiato A, Fabiato F. Calcium induced release of calcium from the sarcoplasmic reticulum of skinned cells from adult human, dog, cat, rabbit, rat, and frog hearts and from fetal and new-born rat ventricles. Ann NY Acad Sci 1978; 307: 491-522.

13 Fleckenstein A. Die Bedeutung der energiereichen Phosphate für Kontraktilität und Tonus des Myokards. Verh Dtsch Ges Inn Med 1964; 70: 81-99.

14 Fleckenstein A, Tritthart H, Döring HJ, Byon YK. Bay a 1040-Ein hochaktiver $\mathrm{Ca}^{++}$antagonistischer Inhibitor der elektro-mechanischen Koppelungsprozesse im Warmblüter-Myokard. Arzneim Forsch 1972; 22: 22-33.

15 Hashimoto K, Takeda K, Katano Y, et al. Effects of niludipine (Bay a 7168) on the cardiovascular system. With a note on its calcium antagonistic effects. Arzneim Forsch 1979; 29: 1368-73.

16 Fleckenstein A, Fleckenstein-Grün G, Byon YK. Fundamentale Herz und Gefässwirkungen des $\mathrm{Ca}^{++}$ antagonischen Koronartherapeutikums Fendilin $\left(\right.$ Sensit $\left.^{\mathrm{R}}\right)$. Arzneim Forsch 1977; 27: 562-71.

17 Fleckenstein-Grün G, Fleckenstein A, Byon YK, Kim $\mathrm{KW}$. Mechanism of action of $\mathrm{Ca}^{++}$antagonists in the treatment of coronary disease with special reference to perhexilene maleate. Proceedings of the symposium on perhexilene maleate. Amsterdam: Excerpta Medica, 1976: $1-22$.

18 Nakajima H, Hoshiyama M, Yamashita K, Kiyomoto A. Effect of diltiazem on electrical and mechanical activity of isolated cardiac ventricular muscle of guinea pig. $\mathcal{F} p n \mathcal{F}$ Pharmacol 1975; 25: 383-92.

19 Henry PD. Calcium ion $\left(\mathrm{Ca}^{++}\right)$antagonists: mechanism of action and clinical applications. Pract Cardiol 1979; 5: 145-56.

20 Cavey D, Vincent JP, Lazdunski $M$. The muscarinic receptor of heart cell membranes. Association with agonists, antagonists, and antiarrhythmic agents. FEBS Lett 1977; 84: 110-4.

21 Nayler W. What is $\mathrm{Ca}^{++}$antagonism? In: Richardson $\mathrm{RG}$, ed. $\mathrm{Ca}^{++}$antagonism. Queenborough: Abbott Laboratories, 1980: 43-7.

22 Fleckenstein A. In discussion of "What is $\mathrm{Ca}^{++}$ antagonism?" Nayler W. In: Richardson RG, ed. $\mathrm{Ca}^{++}$ antagonism. Queenborough: Abbott Laboratories, 1980: 46-7.

23 Fleckenstein A, Döring HJ, Janke J, Byon YK. Basic actions of ions and drugs on myocardial high energy phosphate metabolism and contractility. In: Born GVR, Eichler D, Farah A, Herken H, Welch AD, eds. Handbook of experimental pharmacology. XVI Part 3. Berlin, Heidelberg, New York: Springer Verlag, 1975: 345-405.

24 Singh BN, Roche AHG. Effects of intravenous verapamil on hemodynamics in patients with heart disease. $\mathrm{Am}$ Heart f 1977; 94: 593-9.

25 Van den Brand M, Remme WJ, Meester GT, Tiggelaarde Widt J, de Ruiter R, Hugenholtz PG. Hemodynamic effect of nifedipine (Adalat) in patients catheterized for coronary artery disease. In: Lochner W, Braasch W, 
Kroneberg G, eds. 2nd international Adalat symposium. New therapy of ischemic heart disease. Berlin, Heidelberg, New York: Springer Verlag, 1975: 145-52.

26 Nakayama K, Fleckenstein A, Byon YK, FleckensteinGrün G. Fundamental physiology of coronary smooth muscalature from extramural stem arteries of pigs and rabbits. Eur f Cardiol 1978; 8: 319-35.

27 Fleckenstein-Grün G, Fleckenstein A. Calcium antagonismus, ein Grundprinzip der Vasodilatation. In: Fleckenstein A, Roskamm H, eds. Calcium antagonismus. Berlin, Heidelberg, New York: Springer Verlag, 1980: 191-207.

28 Haastert HP, Fleckenstein A. Ca-dependence of supraventricular pacemaker activity and its responsiveness to Ca-antagonistic compounds (verapamil, D600, nifedipine). Naunyn Schmiedebergs Arch Pharmacol 1975; 287, suppl: R39.

29 Wit AL, Cranefield PF. Effect of verapamil on the sinoatrial and atrioventricular nodes of the rabbit and the mechanism by which it arrests re-entrant atrioventricular nodal tachycardia. Circ Res 1974; 35:413-25.

30 Kohlhardt M, Figulla HR, Tripathi O. The slow membrane channel as the predominant mediator of the excitation process of the sinoatrial pacemaker cell. Basic Res Cardiol 1976; 71: 17-26.

31 Rowland E, Evans T, Krikler D. Effect of nifedipine on atrioventricular conduction as compared with verapamil. Br Heart F 1979; 42: 124-7.

32 Breithardt G, Seipel L, Weibringhaus E, Loogen F. Effects of verapamil on sinus node function in man. Eur f Cardiol 1978; 8: 379-94.

33 Rowe GG, Stenlund RR, Thomsen JH, Corliss RJ, Sialer $S$. The systemic and coronary hemodynamic effects of iproveratril. Arch Int Pharmacodyn 1971; 193: 381-90.

34 Kirchheim H, Gross R. Hemodynamic effects of Adalat in the unanesthetised dog. In: Lochner $\mathbb{W}$, Brasch $\mathbb{W}$, Kroneberg G, eds. 2nd international Adalat symposium. New therapy of ischemic heart disease. Berlin, Heidelberg, New York: Springer Verlag, 1975: 82-90.

35 Luebs EB, Cohen A, Zaleski EJ, Bing RJ. Effect of nitroglycerin, intensain, isoptin and papaverine on coronary flow in man. Am $\mathcal{F}$ Cardiol 1966; 17: 534-41.

36 Kaltenbach M, Schulz W, Kober G. Effects of nifedipine after intravenous and intracoronary administration. $\mathrm{Am}$ f Cardiol 1979; 44: 832-8.

37 Engel H-J, Lichtlen PR. Effect of nifedipine on regional myocardial bloodflow at rest and during rapid atrial pacing. In: Puech $\mathrm{P}, \mathrm{Krebs} \mathrm{R}$, eds. 4th international adalat symposium. New therapy of ischemic heart disease. Amsterdam: Excerpta Medica, 1980: 55-63.

38 Simonsen S, Nitter-Hauge S. Effect of nifedipine (Adalat ${ }^{R}$ ) on coronary hemodynamics in patients with coronary arteriosclerotic disease. Acta Med Scand 1978; 204: 179-84.

39 Goldberg S, Reichek N, Wilson J, Hirshfeld JW Jr, Muller J, Kastor JA. Nifedipine in the treatment of Prinzmetal's (variant) angina. Am f Cardiol 1979; 44: 804-10.

40 Yasue H, Nagao M, Omote S, Takizawa A, Miwa K, Tanaka S. Coronary arterial spasm and Prinzmetal's variant form of angina induced by hyperventilation and Tris-buffer infusion. Circulation 1978; 58: 56-62.
41 Prinzmetal M, Ekmekci A, Kennamer R, Kwoczynski JK, Shubin H, Toyoshima $\mathrm{H}$. Variant form of angina pectoris: previously undelineated syndrome. FAMA 1960; 174: 1794-800.

42 Maseri A, Mimmo R, Chierchia S, et al. Coronary artery spasm as a cause of acute myocardial ischemia in man. Chest 1975; 68: 625-33.

43 Theroux P, Waters DD, Affaki GS, Crittin J, Bonan R, Mizgala HF. Provocative testing with ergonovine to evaluate the efficacy of treatment with calcium antagonists in variant angina. Circulation 1979; 60: 504-10.

44 Heupler FA Jr, Proudfit WL. Nifedipine therapy for refractory coronary arterial spasm. Am $\mathcal{F}$ Cardiol 1979; 44: 798-803.

45 Nakamura M, Koiwaya Y. Beneficial effect of diltiazem, a new anti-anginal drug, on angina pectoris at rest. $\mathrm{fpn}$ Heart f 1979; 20: 613-21.

46 Parodi O, Maseri A, Simonetti I. Management of unstable angina at rest by verapamil. A double-blind cross-over study in coronary care unit. Br Heart $\mathcal{F} 1979$; 41: $167-74$.

47 Antman E, Muller J, Goldberg S, et al. Nifedipine therapy for coronary artery spasm. N Engl $\mathcal{F}$ Med 1980; 302: 1269-73.

48 Moskowitz RM, Piccini PA, Nacarelli GV, Zelis R. Nifedipine therapy for stable angina pectoris. Preliminary results of effects on angina frequency and treadmill exercise response. Am $\mathcal{F}$ Cardiol 1979; 44: 811-6.

49 Lynch P, Dargie H, Krikler S, Krikler D. Objective assessment of antianginal treatment: a double-blind evaluation of propranolol, nifedipine, and their combination. $B r$ Med F 1980; 281: 184-7.

50 Neumann M, Luisada AA. Double-blind evaluation of orally administered iproveratril in patients with angina pectoris. Am F Med Sci 1966; 251: 552-6.

51 Livesley B, Catley PF, Campbell RC, Oram S. Doubleblind evaluation of verapamil, propranolol and isosorbide dinitrate against a placebo in the treatment of angina pectoris. Br Med F 1973; i: 375-8.

52 Bala Subramanian V, Lahiri A, Paramasivan R, Raftery EB. Verapamil in chronic stable angina. A controlled study with computerised multistage treadmill exercise. Lancet 1980; i: 841-4.

53 De PontiC, Mauri F, Ciliberto GR, Carù B. Comparative effects of nifedipine, verapamil, isosorbide dinitrate and propranolol on exercise induced angina pectoris. Eur $\mathcal{F}$ Cardiol 979; 10: 47-58.

54 Ekelund LG, Orö L. Anti-anginal efficiency of nifedipine with and without a beta-blocker studied with exercise test. A double blind randomised subacute study. Clin Cardiol 1979; 2: 203-11.

55 Oakley GD, Fox KM, Dargie HJ, Selwyn AP. Objective assessment of treatment in severe angina. $\mathrm{Br} \mathrm{Med} \mathcal{F}$, 1979; 1: 1540.

56 Jennings RB, Baum JH, Herdson PB. Fine structural changes in myocardial ischemic injury. Arch Pathol 1965; 79: 135-43.

57 Nayler WG, Fassold E, Yepez C. Pharmacological protection of mitochondrial function in hypoxic heart muscle: effect of verapamil, propranolol, and methylprednisolone. Cardiovasc Res 1978; 12: 152-61. 
58 Sobel B. Propranolol and threatened myocardial infarction. N Engl F Med 1979; 300: 191-2.

59 Smith HJ, Goldstein RA, Griffith JM, Kent KM, Epstein SE. Regional contractility. Selective depression of ischemic myocardium by verapamil. Circulation 1976; 54: 629-35.

60 Nayler WG, Grau A, Slade A. A protective effect of verapamil in hypoxic heart muscle. Cardiovasc Res 1976; 10: 650-62.

61 Smith HJ, Singh BN, Nisbett HD, Norris RM. Effects of verapamil on infarct size following experimental coronary occlusion. Cardiovasc Res 1975; 9: 569-78.

62 Henry PD, Schuchleib R, Clark RE, Perez JE. Effect of nifedipine on myocardial ischemia: analysis of collateral flow pulsatile beat and regional muscle shortening. $A m f$ Cardiol 1979; 44: 817-24.

63 Nayler WG, Yepez CE, Poole-Wilson PA. The effect of $\beta$ adrenoceptor and $\mathrm{Ca}^{2+}$ antagonist drugs on the hypoxiainduced increase in resting tension. Cardiovasc Res 1978; 12: 666-74.

64 Magee PG, Flaherty JT, Bixler TJ, et al. Comparison of myocardial protection with nifedipine and potassium. Circulation 1979; 60, suppl I: 151-7.

65 Weishaar R, Ashikawa K, Bing RJ. Effect of diltiazem, a calcium antagonist, on myocardial ischemia. $A m \mathcal{J}$ Cardiol 1979; 43: 1137-43.

66 Henry PD, Clark RE, Williamson JR. Protection of the globally ischemic heart with calcium antagonists. In: Fleckenstein A, Roskamm H, eds. Calcium antagonismus. Berlin, Heidelberg, New York: Springer Verlag, 1980: 181-90.

67 Ruigrok TJC, Boink ABTJ, Slade A, Zimmerman ANE, Meijler FL, Nayler WG. The effect of verapamil on the calcium paradox. Am F Pathol 1980; 98: 769-80.

68 Selwyn AP, Welman E, Fox K, Horlock P, Pratt T, Klein $M$. The effects of nifedipine on acute experimental myocardial ischemia and infarction in dogs. Circ Res 1979; 44: 16-23.

69 Jariwalla AG, Anderson EG. Production of ischaemic cardiac pain by nifedipine. $B r$ Med F 1978; i: 1181 .

70 Krikler DM, Spurrell RAJ. Verapamil in the treatment of paroxysmal supraventricular tachycardia. Postgrad Med f 1974; 50: 447-53.

71 Wellens HJJ, Tan SL, Bär FWH, Düren DR, Lie KI, Dohmen HM. Effect of verapamil studied by programmed electrical stimulation of the heart in patients with paroxysmal re-entrant supraventricular tachycardia. $\mathrm{Br}$ Heart $\mathcal{F}$ 1977: 39: 1058-66.

72 Curry PVL, Rowland E, Fox KM, Krikler DM. The relationship between posture, blood pressure and electrophysiological properties in patients with paroxysmal supraventricular tachycardia. Arch Mal Coeur 1978; 71: 293-9.

73 Härtel G, Hartikainen M. Comparison of verapamil and practolol in paroxysmal supraventricular tachycardia. Eur F Cardiol 1976; 4: 87-90.

74 Schamroth L, Krikler DM, Garrett C. Immediate effects of intravenous verapamil in cardiac arrhythmias. $\mathrm{Br}$ Med f 1972; i: 660-2.

75 Klein HO, Pauzner H, Di Segni E, David D, Kaplinsky E. The beneficial effects of verapamil in chronic atrial fibrillation. Arch Intern Med 1979; 139: 747-9.
76 Rowland E, Krikler DM. Relation between symptoms, initiation zone, and oral antiarrhythmic treatment in re-entry atrioventricular tachycardia (abstract). Br Heart f 1980; 43: 718-9.

77 Husaini MH, Kvasnicka J, Rydén L, Holmberg S. Action of verapamil in sinus node, atrioventricular, and intraventricular conduction. Br Heart f 1973; 35: 734-7.

78 Opie LH. Drugs and the heart. III Calcium antagonists. Lancet 1980; i: 806-10.

79 Ferlinz J, Easthope JL, Aronow WS. Effects of verapamil on myocardial performance in coronary disease. Circulation 1979; 59: 313-9.

80 Cranefield PF, Aronson RS, Wit AL. Effect of verapamil on the normal action potential and on a calciumdependent slow response of canine cardiac Purkinje fibers. Circ Res 1974; 34: 204-13.

81 El-Sherif, Lazzara R. Re-entrant arrhythmias in the late myocardial infarction period 7. Effect of verapamil and D600 and the role of the "slow channel". Circulation 1979; 60: 605-15.

82 Wellens HJJ, Bär FWH, Lie KI, Düren DR, Dohmen HJ. Effect of procainamide, propranolol and verapamil on mechanism of tachycardia in patients with chronic recurrent ventricular tachycardia. Am $\mathcal{F}$ Cardiol 1977; 40: $579-85$.

83 Fazzini PF, Marchi F, Pucci P. Effects of verapamil in ventricular premature beats of acute myocardial infarction. Acta Cardiol (Brux) 1978; 33: 25-9.

84 Heng MK, Singh BN, Roche AHG, Norris RM, Mercer CJ. Effects of intravenous verapamil on cardiac arrhythmias and on the electrocardiogram. Am Heart $\mathcal{F}$ 1975; 90: 487-98.

85 Kimura E, Tanaka K, Mizuno K, Honda Y, Hashimoto H. Suppression of repeatedly occurring ventricular fibrillation with nifedipine in variant forms of angina pectoris. Jpn Heart J 1977; 18: 736-42.

86 Kaumann AJ, Aramendia P. Prevention of ventricular fibrillation induced by coronary ligation. I Pharmacol Exp Ther 1968; 164: 326-32.

87 Brooks WW, Verrier RL, Lown B. Protective effect of verapamil on vulnerability to ventricular fibrillation during myocardial ischaemia and perfusion. Cardiovasc Res 1980; 14: 295-302.

88 Atterhög JH, Ekelund LG. Haemodynamic effects of intravenous verapamil at rest and during exercise in subjectively healthy middle-aged men. Eur $\mathcal{f}$ Clin Pharmacol 1975; 8: 317-22.

89 D'Oliveira J, Calderon NR, Garcilazo E, Patricio J, Tenreyro E. Haemodynamic changes after a single dose of Nifedipine (Adalat). In: Jatene AD, Lichtlen PR, eds. 3rd international Adalat symposium. New therapy of ischemic heart disease. Amsterdam: Excerpta Medica, 1976: 50-4.

90 Wei JW, Janis RA, Daniel EE. Alterations in calcium transport and binding by the plasma membrane of mesenteric arteries from spontaneously hypertensive rats. Blood Vessels 1977; 14: 55-64.

91 Aoki K, Yoshida T, Katos Tazumi K, Sato I, Takikawa $\mathrm{K}$, Hoffa $\mathrm{K}$. Hypotensive action and increased plasma renin activity by a $\mathrm{Ca}^{2+}$ (nifedipine) in hypertensive patients. Fpn Heart $\mathcal{F}$ 1976; 17: 479-83. 
92 Dargie HJ, Lynch P, Krikler S, Krikler D. A comparison of the hypotensive effect of calcium antagonism and beta blockade (abstract). Eur $\mathcal{F}$ Clin Invest 1980; 10: 9.

93 Laaser U, Meurer KA, Kruger H, Kaufman W. Clinical studies on the combined effects of various antihypertensive agents and Adalat. In: Lochner W, Braasch W, Kroneberg G, eds. 2nd international Adalat symposium. New therapy of ischemic heart disease. Berlin, Heidelberg, New York: Springer Verlag, 1975: 285-9.

94 Lewis GRJ, Morley KD, Lewis BM, Bones PJ. The treatment of hypertension with verapamil. NZ Med $\mathcal{F}$ 1978; 87: 351-4.

95 Lewis GRJ, Morley KD, Maslowski AH, Bones PJ. Verapamil in the management of hypertensive patients. Aust NZ J Med 1979; 9: 62-4.

96 Lossnitzer K, Janke J, Hein B, Stauch M, Fleckenstein A. Disturbed myocardial metabolism: a possible pathogenic factor in the hereditary cardiomyopathy of the Syrian hamster. In: Fleckenstein A, Rona G, eds. Recent advances in studies on cardiac structure and metabolism. vol 6. Pathophysiology and morphology of myocardial cell alteration. Baltimore: University Park Press, 1975: 207-18.

97 Kaltenbach M, Hopf R, Keller M. Calcium antagonische Therapie bei hypertroph-obstruktiver Kardiomyopathie. Dtsch Med Wochenschr 1976; 101: 1284-7.

98 Kaltenbach M, Hopf R, Kober G, Bussmann W-D, Keller M, Petersen Y. Treatment of hypertrophic obstructive cardiomyopathy with verapamil. $\mathrm{Br}$ Heart $\mathcal{F}$ 1979 ; 42: 35-42.

99 Troesch M, Hirzel HO, Jenni R, Krayenbühl HP. Reduction of septal thickness following verapamil in patients with assymetric septal hypertrophy (ASH) (abstract). Circulation 1979; 59-60: suppl II-155.

100 Rosing DR, Kent KM, Borer JS, Seides SF, Maron BJ, Epstein SE. Verapamil therapy: a new approach to the pharmacologic treatment of hypertrophic cardiomyopathy. 1. Hemodynamic effects. Circulation 1979; 60: 1201-7.

101 Rosing DR, Kent KM, Maron BJ, Epstein SE. Verapamil therapy: a new approach to the pharmacologic treatment of hypertrophic cardiomyopathy. II. Effects on exercise capacity and symptomatic status. Circulation 1976; 60: 1208-13.

102 Goodwin JF, Krikler DM. Arrhythmia as a cause of sudden death in hypertrophic cardiomyopathy. Lancet 1976; ii: 937-40.

103 McKenna W, Deanfield J, Chetty S, Faruqui A, Oakley C, Goodwin J. Arrhythmia and mortality in hypertrophic cardiomyopathy (abstract). Br Heart f 1980; 43: 719.

Requests for reprints to Dr Dennis Krikler, Royal Postgraduate Medical School, 150 Ducane Road, London W12 0HS. 